Article

\title{
Diversity in Protected Area Governance and Its Implications for Management: An Institutional Analysis of Selected Parks in Iceland
}

\author{
Jukka Siltanen ${ }^{1,2, * \mathbb{D}}$, Jon Geir Petursson ${ }^{1,2} \mathbb{D}$, David Cook ${ }^{1,2} \mathbb{D}$ and Brynhildur Davidsdottir ${ }^{1,2}$ \\ 1 Environment and Natural Resources, School of Engineering and Natural Sciences, University of Iceland, \\ 102 Reykjavík, Iceland; jgp@hi.is (J.G.P.); dac@hi.is (D.C.); bdavids@hi.is (B.D.) \\ 2 Environment and Natural Resources, School of Social Sciences, University of Iceland, 102 Reykjavík, Iceland \\ * Correspondence: jks16@hi.is
}

check for

updates

Citation: Siltanen, J.; Petursson, J.G.; Cook, D.; Davidsdottir, B. Diversity in Protected Area Governance and Its Implications for Management: An Institutional Analysis of Selected Parks in Iceland. Land 2022, 11, 315. https://doi.org/10.3390/ land11020315

Academic Editors: Bastian Bertzky, Colleen Corrigan and Susan Snyman

Received: 28 January 2022

Accepted: 16 February 2022

Published: 21 February 2022

Publisher's Note: MDPI stays neutral with regard to jurisdictional claims in published maps and institutional affiliations.

Copyright: (c) 2022 by the authors. Licensee MDPI, Basel, Switzerland. This article is an open access article distributed under the terms and conditions of the Creative Commons Attribution (CC BY) license (https:/ / creativecommons.org/licenses/by/ $4.0 /)$.

\begin{abstract}
A protected area (PA) is essentially a governance system, a spatially defined area encompassing natural and/or cultural attributes, governed by a set of actors with different roles and institutional frameworks. There are many types of PA governance systems, guided by historical-, site-specific- and context-dependent factors. This study has the objective to advance understanding of PA governance systems, their diversity and the implications for management. We take the case of Iceland and five of its major PAs. We develop an analytical framework for the study of PA governance systems, investigating their evolutionary trajectories, conducting a comparative institutional analysis of their environmental governance systems (EGS), and assessing their management implications using nature-based tourism as a key variable. We find this framework effective and applicable beyond this study. We find great diversity in the five PA governance systems that has not come by chance but deliberately negotiated in their protracted establishment trajectories. At the individual park level, such PA diversity can be embraced as a sign of an adaptive approach to governance instead of a one-size-fits-all solution while at the national level, however, such fragmentation constitutes coordination challenges. Our analysis of the current portfolio of PA governance systems reveals they accommodate most of the needed management measures, but a problem remains concerning scattered and locked-in individual governance systems that do not support coordinated action and sharing of expertise and resources. This calls upon policy guidance with more formal coordination, such as a legal and national policy framework embracing PA governance diversity, but also securing more coordinated measures for day-to-day management.
\end{abstract}

Keywords: conservation; environmental governance systems (EGS); institutional fit; legitimacy; park service

\section{Introduction}

A protected area (PA) is essentially a governance system. It is a spatially defined area encompassing natural and/or cultural attributes and services, governed by a set of actors with different roles and institutional frameworks [1,2]. PAs represent a major land cover for most nations and have expanded rapidly in recent decades, currently covering, globally, nearly $17 \%$ of terrestrial areas in over 250,000 designations [3]. PAs are organised according to a variety of spatial and natural attributes, determining conservation goals, protection categories, and a wide range of allowed human activities [4,5]. Given this scale and diversity, there are also major differences in the PA approach to governance and in the effectiveness of their governance systems [6-9].

Parallel to the relatively recent expansion, PA governance has also evolved significantly, both in management approaches and policy objectives [4,10,11]. Earlier PAs were mainly focused on nature conservation efforts but gradually social and economic aspects, such as keeping rural areas populated and supporting local livelihoods, have become more 
and more important $[9,12,13]$. Recent studies have suggested that employing inclusive governance processes and generating positive social impacts outweigh the importance of ecological effectiveness for local generating support towards establishment of PAs [14].

In a global perspective, PAs are operationalised via four broad main governance types: government-governed by the central government; private-governed by private actors; indigenous-governed by indigenous people; or co-managed-shared governance among actors at different levels $[15,16]$. This broad governance categorisation is, however, very general and leaves out many variations and approaches. Within each governance type there is great variety in governance elements such as of actor roles and institutional factors, and thus there are generally no "one-size-fits-all" solutions or models. Moreover, there is a need to consider the different trajectories of establishment and their context-dependentand site-specific conditions [11].

Governance systems are supposed to be able to counter undesirable outcomes and deliver desired outcomes [1,17]. PAs are widely regarded as policy vehicles for rural development where tourism is seen as the key economic driver [18-20], and positive or negative socioeconomic impacts of PAs depend largely on their governance and management practises [21]. During their operation, PAs are exposed to multiple internal and external challenges [22]. However, once established, tourism can be defined as the main PA managerial challenge, given the human attraction of the various natural and cultural qualities such areas encompass $[23,24]$. Therefore, PA governance systems are expected to provide structures of governance to secure the conservation of the natural and cultural attributes and services of the PAs and concurrently drive sustainable outcomes linked to tourism activities.

Developments and challenges in PA governance are getting more attention considering international policy goals and expectations of significant PA expansion [13]. The European Commission [25] and UN Convention for Biological Diversity (CBD) [26] are targeting $30 \%$ terrestrial and marine PA coverage by 2030, nearly doubling terrestrial PAs and tripling marine PAs in just 10 years, and making designated PA land cover second only to agriculture [27]. To allow new PAs to be established effectively and existing ones expanded to facilitate compliance with the new targets, better understanding is needed regarding the diversity of formulation and implementation of protected area governance systems in different contexts and how different governance systems are fit to address new management challenges.

Iceland provides an interesting case to analyse the diversity of PA governance systems and its implications for management. It has allocated approximately one-quarter of its land under protection, with several different governance structures that have been shaped by different contexts, negotiations and socioeconomic factors and resulted in multiple governance systems with different legal bases $[11,28]$. Due to the importance of naturebased tourism as a major economic sector in Iceland, much attention has recently been given to the protected area estate and its economic role (e.g., $[29,30])$. At the same time, a tourism boom from 2010 to 2019 and high visitor numbers have resulted in tourism pressure becoming by far the biggest management challenge for the Icelandic PAs [31].

This study will use the example of five case studies from Iceland's PAs to advance understanding of PAs as governance systems, how governance diversity manifests in different systems and what implications diversity has on their performance. We therefore explore the following research questions:

1. What are the evolutionary trajectories of the selected PAs and factors shaping their governance systems? What can we learn from these processes for future PAs?

2. What are the attributes of the different PA governance systems and how do they compare?

3. What are the management implications of the different governance systems, using nature-based tourism as a key analytical variable?

4. What are the policy implications of the findings? 


\section{Materials and Methods}

\subsection{Background: Protected Area Governance in Iceland}

Iceland is a sparsely populated country in the North Atlantic with a land area of $103,000 \mathrm{~km}^{2}$, two-thirds of the 374,830 population living in the capital region of Reykjavik and a population density of only 3.6 per $\mathrm{km}^{2}$ [32,33]. A significant part of the country is covered by uninhabitable highlands; less than $1 \%$ of the land area is built up in urban/recreational settings and around 3\% devoted to agriculture [34].

Iceland has gradually been building its PA estate and currently PAs cover over onequarter of the country in 122 designations [35]. Despite comparatively high coverage, PAs are a relatively recent phenomenon in Iceland. Apart from Pingvellir National Park, whose establishment in 1930 was timed to celebrate a millennium of the Icelandic Parliament, most PAs have been established after revision of the Nature Protection Act in 1971. Some of the largest area additions, such as Vatnajökull National Park and its appendices, are from 2007 onwards [28].

The formal governance features of Icelandic PAs are generally defined according to two main pathways for their establishment. Firstly, the general Nature Conservation Act 60/2013 [36] provides the legal framework for different categories of PAs, mainly following the IUCN management categorisation [5], and secondly, site-specific legislation which allows for a wide range of negotiation and flexibility regarding the governance system, actors' structure and institutional frameworks [28].

There are some defining factors of land governance in Iceland that impact and influence PA governance systems and are important for understanding regarding this study.

Iceland has two levels of government: central and local. The local governments enjoy a high level of sovereignty and are responsible for spatial planning, giving them significant control over land-related decision making within their jurisdictions. PA establishment and governance therefore commonly becomes an issue in relation to decision-making power between those two levels of government. These power relations have resulted in the central government rarely imposing PA establishment without seeking consent from the respective local government [11].

The "right to roam" principle on uncultivated land (almannaréttur) is another important factor for understanding the Icelandic case and in particular tourism management challenges following a similar trait as in other Nordic countries [37]. This allows for people to travel freely on and across land regardless of property rights. However, this right does not clearly differentiate between domestic wanderers or large-scale tourism, causing significant challenges for visitor management, including the issues of access, crowding and collecting service fees in the popular PAs.

There has been considerable debate around land development decisions and nature conservation, much of it focused on energy utilisation, and this debate has affected the establishment of many PAs [38-40]. Since 2010, the growth of nature-based tourism in Iceland has been particularly rapid, from around 500,000 to over 2 million annual visitors in 2018-2019, and over a million people visiting the most popular national parks [30,41]. This needs to be understood relative to the small overall population, capacity of the national infrastructure in general and PA management in particular [42]. Following the tourism boom, the economic value of PAs from nature-based tourism and recreation has been increasingly recognised in Iceland [30], and before the COVID-19 pandemic, tourism had become by far the largest economic activity with respect to export incomes [43].

\subsection{Analytical Framework and Methodology}

\subsubsection{Environmental Governance Systems (EGS)}

The study of environmental governance systems is based on the rich scholarship on institutions and common property resources [1,2,44,45]. We understand institutions as the socially constructed rules, norms and conventions to coordinate our interactions and, in the case of environment and natural resources, to steer our use towards desired outcomes [17]. A governing system consists of multiple actors and institutions involved in governance of 
a particular resource $[2,45,46]$. The term governance system can then be understood as a social system for certain environmental and natural resources features such as a PA, with a set of actors with different roles and powers, and the dual role of institutions for actor-actor coordination as their coordination with the resource. We develop an environmental governance system framework based and expanded from Vatn [2] (Figure 1). This framework embeds the key elements for our analysis and gives an overview of the phases and actors in PA management from establishment to operation and outcomes. This connects to our research questions, hence: RQ1 focuses on the trajectory phase; RQ2 on the governance system; RQ3 on the interactions and outcomes; and RQ4 provides policy recommendation on the operational part of the system.

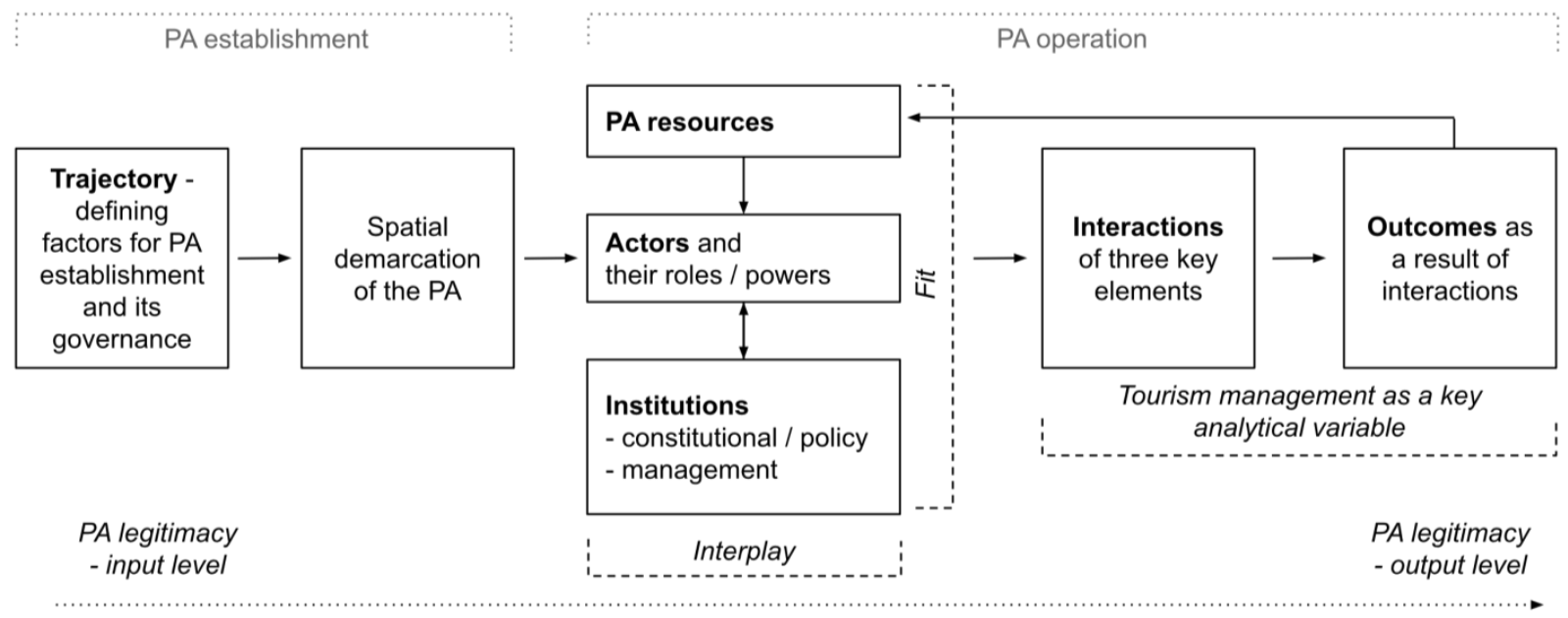

Figure 1. Environmental governance system (EGS) framework for the analysis of PAs (adapted and expanded from [2]).

We can identify the main variables of the framework we set out to analyse.

Firstly, EGSs are commonly an outcome of negotiations, power-contested tugs-of-war over multiple interests shaped by their development trajectory. Each PA has its own context and origins in terms of why, how and by whom it is protected.

Secondly, the area is usually spatially demarcated via legal enshrinement, defining the PA resources with certain natural and cultural attributes. These attributes, for example, size, ecological sensitivity, access, popularity and vulnerability to natural threats (e.g., climate change) or economic uses (e.g., resource-use within or around PA), directly affect both the policies and actions as well as protection outcomes.

Thirdly, the EGS itself has three key variables: the attributes of the PA resources, the actors with different roles and powers and the institutional structures for conservation and management of the area. Key actors in the framework can be understood as political, economic and civil society actors. Commonly, the institutional structures can be defined as either those operating on the constitutional or policy level, or on the management level of on-site rules, norms and conventions [2].

Government organisations and political actors at different levels shape the policies concerning PAs in interaction with the economic actors (e.g., resource users ranging from local farmers and tourism services to heavy industry) and civil society. Interactions of the policies, institutions and their implementation between the actors defines the outcomes of the EGS. Governance systems can be analysed and contextualised by studying the different variables of the system and how they interact.

\subsubsection{Analysis of EGS Outcomes and Performance}

The EGS performance is an outcome of multiple interactions between the individual variables in the framework. To examine and discuss the EGS performance, we employ 
the concepts of legitimacy of the governance systems, and then their institutional fit and interplay.

The concept of legitimacy is useful for the understanding of EGS performance, and this notion is comprehended as involving not only legality but also how the systems incorporate and justify authority [47]. We differentiate between input and output legitimacy [2,48]:

- Input legitimacy concerning the appropriateness of the decision-making process, both from a legal process standpoint and its capacity to represent the interests of different actors in the governance system;

- Output legitimacy in terms of effectiveness (capacity to ensure goals are reached), efficiency (ability to reach goals cost-effectively) and the problem-solving quality of the laws and rules.

Input legitimacy is particularly interesting in the analysis of the trajectories of PA establishment. For this study, we take procedural legality as given, and focus on the participation and representation aspect wherein a significant shift has happened in recent decades concerning the establishment of PAs (e.g., [9]). Extensive stakeholder participation in PA design and management are also implied in the Aichi and upcoming CBD targets for PA expansion, which call for all PAs to be 'equitably managed' $[6,26]$. Concerning output legitimacy, our study focuses mainly on effectiveness and the EGS capacity for problem-solving and adaptation.

We employ the interrelated concepts of fit and interplay to examine the governance system's performance $[17,49]$. The concept of fit can be used to analyse how a governance system matches the spatial, temporal and functional attributes of the natural system. In Young's concept, spatial attributes are central to evaluating whether the governance system fits the natural system it is intended to manage [17]. Temporal fit represents how the governance system is able to adapt and respond to challenges in a timely manner. Functional fit represents the match between the ecosystem and institutional arrangements, e.g., features in the ecosystem that are not accounted for by the institutional arrangements signal poor functional fit [50]. There can be several solutions offering a good institutional fit for a given situation.

The concept of interplay describes how different institutions interact and impact other institutions [49]. Interplay takes place on horizontal (on the same level) and vertical (hierarchical) levels. As governance systems do not operate in an institutional vacuum, the different forces of interplay are important to understand how such governance systems perform like in our case of protected areas.

This study does not attempt to assess the conservation outcomes of the different PA governance systems. Such data on status and transition of the individual park natural resources in Iceland has not been available. However, new PA natural resources monitoring program on a national scale entered in force in 2021 and will in the coming years generate bio- and geophysical data, forming a basis for such study [51].

\subsection{Methodology and Data}

For the analysis of the trajectories leading to establishment of each selected Icelandic PA, we carried out an extensive narrative literature review (e.g., [52]) of these relatively well-documented processes in Iceland. To understand the origins and context of each PA, we aimed to answer the following questions from the identified literature: what the origin of the idea was, the timeline of the process, who/what was the driver for the establishment, who were the main stakeholders, what were the key issues in the negotiations and which were the key enabling factors that paved way for the PA.

We conducted an institutional analysis of the PA governance systems by analysing the respective legal and regulatory frameworks, employing the EGS model (Figure 1). Then we performed a content analysis of the PA management plans to evaluate what measures are proposed and offered for the management of nature-based tourism in the areas. Finally, we conducted an in-depth, semi-structured interview with a park director or head warden from each PA to get insight on how the governance structures and management plans 
respond to actual needs in park management. The interviews were conducted remotely using Teams. They were recorded and subsequently transcribed; the question outline is provided in Appendix A. Topics related to the EGS analysis and policy implications were identified and are referenced as part of the analysis where applicable. Since Breiðafjörður Nature Reserve does not have a park administration or day-to-day management staff, no such interview was conducted in this case.

\subsection{Sites Selected for the Study}

This study focuses on the analysis of five significant and distinct PAs with varying governance structures, contextual settings and spatial scales: Vatnajökull NP, Pingvellir NP, Mývatn-Laxá Conservation Area, Snæfellsjökull NP and Breiðafjörður Nature Reserve (Figure 2; Table 1). In this analysis, we include all three national parks in Iceland and all PAs that operate under a site-specific legislation providing a comprehensive overview of the main governance systems for formally protected areas in Iceland.

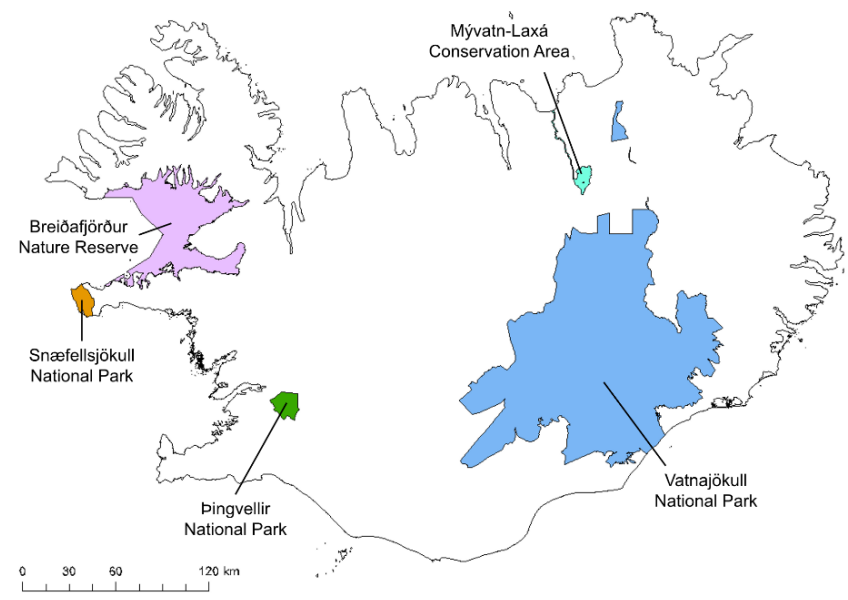

Figure 2. Map of Iceland with the PAs selected for this study.

Table 1. Description of selected PAs in the study.

\begin{tabular}{|c|c|c|c|c|c|}
\hline & Pingvellir & Mývatn-Laxá & Breiðafjörður & Snæfellsjökull & Vatnajökull \\
\hline Description & $\begin{array}{l}237 \mathrm{~km}^{2} \\
\text { Close to the capital } \\
\text { region in } \\
\text { South-West Iceland. } \\
\text { World Heritage Site. } \\
\text { IUCN (II). }\end{array}$ & $\begin{array}{l}153 \mathrm{~km}^{2} \text { lake, river and } \\
200 \mathrm{~m} \text { wide lake shore } \\
\text { and riverbank area in } \\
\text { North-East Iceland. } \\
\text { Ramsar site. No single } \\
\text { IUCN category defined. }\end{array}$ & $\begin{array}{l}200 \mathrm{~km}^{2} \text { (excluding the } \\
\text { sea beyond tidal coast) } \\
\text { fjord between } \\
\text { Snæfellsness and West } \\
\text { Fjords. } \\
\text { IUCN (V). }\end{array}$ & $\begin{array}{l}170 \mathrm{~km}^{2} \\
\text { Tip of Snæfellsness } \\
\text { peninsula in West } \\
\text { Iceland. IUCN (II). }\end{array}$ & $\begin{array}{c}14,141 \mathrm{~km}^{2} \\
\text { Covers a large part of } \\
\text { south-eastern } \\
\text { highlands, extensions } \\
\text { in North Iceland. } \\
\text { World Heritage Site. } \\
\text { IUCN (II). }\end{array}$ \\
\hline $\begin{array}{l}\text { Key natural and } \\
\text { cultural } \\
\text { attributes }\end{array}$ & $\begin{array}{c}\text { Historical } \\
\text { parliament site, } \\
\text { and rift valley } \\
\text { between } \\
\text { tectonic plates } \\
\text { containing a lake } \\
\text { system. }\end{array}$ & $\begin{array}{c}\text { Protected wetland area } \\
\text { around a lake and river } \\
\text { system. Rich } \\
\text { vegetation and birdlife. } \\
\text { Surrounding volcanic } \\
\text { and geothermal } \\
\text { attractions. }\end{array}$ & $\begin{array}{l}\text { Large shallow bay with } \\
\text { over } 3000 \text { islands, islets } \\
\text { and skerries and an } \\
\text { exceptional combination } \\
\text { of natural features, bird } \\
\text { and plant life, and } \\
\text { cultural and historical } \\
\text { heritage. }\end{array}$ & $\begin{array}{l}\text { Snæfellsjökull glacier } \\
\text { and } \\
\text { volcano. Unique } \\
\text { volcanic } \\
\text { landscapes by the sea. } \\
\text { Cultural and } \\
\text { historical heritage. }\end{array}$ & $\begin{array}{l}\text { The shaping forces of } \\
\text { fire and ice. } \\
\text { Vatnajökull ice cap } \\
\text { dominates the park } \\
\text { in the central } \\
\text { highlands; also } \\
\text { contains large and } \\
\text { varied regions to the } \\
\text { north, west and } \\
\text { south Iceland. }\end{array}$ \\
\hline $\begin{array}{l}\text { Relevance to } \\
\text { study }\end{array}$ & $\begin{array}{l}\text { First NP in Iceland. } \\
\text { Special status under } \\
\text { parliament. Single } \\
\text { most visited PA } \\
\text { location. }\end{array}$ & $\begin{array}{l}\text { Most popular PA } \\
\text { location in the north. } \\
\text { Managed under } \\
\text { site-specific legislation. }\end{array}$ & $\begin{array}{l}\text { Site-specific legislation } \\
\text { using a local } \\
\text { management model. } \\
\text { Limited number of } \\
\text { visitors. }\end{array}$ & $\begin{array}{l}\text { Only NP under the } \\
\text { generic Nature } \\
\text { Conservation Act. }\end{array}$ & $\begin{array}{c}\text { Innovative } \\
\text { co-management } \\
\text { model. High } \\
\text { visitation numbers. }\end{array}$ \\
\hline $\begin{array}{l}\text { Peak annual } \\
\text { visitor numbers }\end{array}$ & $1,526,523[30]$ & 409,091 [30] & $\begin{array}{l}\text { Ferry 6-8/2019: 32,588; } \\
\text { Flatey island: } 11,982[53]\end{array}$ & $392,168[30]$ & $\begin{array}{c}735,728[30] \\
\text { (at Skaftafell } \\
\text { visitor centre) }\end{array}$ \\
\hline
\end{tabular}




\section{Results and Discussion}

\subsection{Historical Contexts and Trajectories Shaping PA Establishment and Approach to Governance}

Pingvellir NP has a unique history among the Icelandic PAs. The idea for the park was raised by the State Antiquarian in 1907, referring to international development in conservation and pioneering park establishment such as Yellowstone in the US, and identifying locations in Iceland he deemed of high conservation value [54]. Another article [55] triggered more public discussion about the park and 15 years later the Act 59/1928 for the protection of Pingvellir passed parliament [56]. The park was formally established in 1930 celebrating the establishment of the Icelandic Parliament in 930 CE in the heart of the park. There were no existing nature conservation laws as this was the first PA in Iceland, and since it centred around one of the nation's most valuable cultural-historic sites, the process was parliament-driven and had strong support from the public. This was based on the idea that the parliament site and surrounding rift valley would be conserved as a shrine for the future generations [56]. Pingvellir's legislation was not updated until it became an NP through Act 47/2004 [57].

Mývatn-Laxá Conservation Area has its origins in Iceland's first major conservation versus resource utilisation conflict [58]. The Laxá river flowing out of Lake Mývatn had already been dammed in the 1940s and 1950s for two power stations, and plans for a third one with a 57-metre-high dam were proposed in 1968 [59,60]. This plan would have submerged most of the river valley, triggering a fierce debate both locally and nationally about the lands of the farmers in the valley and of the future implications for nature in the area. Regardless, the plan got a green light from the local government who wanted to ensure sufficient power generation capacity for the growing population and industries in the city of Akureyri and the construction started. Local farmers started a conservation association for Mývatn and Laxá, and during the height of the debates in 1970, members of the association used dynamite to blow up one dam of the original power plants [61]. The plans to build the new dam were turned down by the national government, yet the construction continued, triggering several new lawsuits from the local landowners. Finally, the state stepped in to lead difficult negotiations between the landowners and the power company, and a settlement was reached in 1973; a small power plant not affecting the water levels was allowed to be finished and the state funded pathways for migratory fish to bypass the dams, paid the costs of the pending lawsuits and established the PA under site-specific legislation allowing existing uses in 1974 [59].

The idea of protecting Breiðafjörður was presented in parliament in 1978 and agreed as a parliamentary resolution in 1979, but this agenda only moved forwards in 1993 after local councillors presented the idea again with support of the Minister for Environment at the time $[62,63]$. The idea of creating a conservation area and having site-specific legislation was facilitated by the law on the protection of Mývatn-Laxá from 1974, and formulated in several meetings in the local municipalities $[64,65]$. Consensus for the protection was reached in December 1993 with a draft for the law. The law proposal was submitted to parliament in 1994 and passed as Act 54/1995 [66]. Establishment of the Breiðafjörður Nature Reserve was particularly strongly driven by local municipalities in comparison to many other PAs in Iceland; local control of the PA, spatial planning and traditional land and marine resource uses were central themes in the negotiations. Securing these rights ensured local support for the law, leading to a site-specific law and locally managed governance model [66].

There was a long trajectory following the establishment of Snæfellsjökull NP. The idea of a national park in the area, including the iconic glacier, was proposed by a Minister and the chairman of the Nature Conservation Council (Náttúruverndarráð) in the early 1970s [67]. The area was inspected by the Council in 1974, and a proposal was made by them in 1977 for a nature reserve under the glacier [67]. However, official parliamentary preparations began only in 1993 and a parliamentary proposal was submitted in 1994, with two committees working on the idea from 1994 until 2001 when the park opened [67-70]. Since the beginning, local champions from the municipalities surrounding 
the park, the Federation of Municipalities in West-Iceland and local MPs were active participants in the negotiations and preparatory work with the Ministry for Environment, who led the process [67-70]. This process was generally low on conflict and characterised by mutual trust, so site-specific legislation or other special arrangements were not requested in the negotiations; the park was established under the conditions of the general Nature Conservation Act and is still the only such NP in the country.

Vatnajökull NP was formed as a merger and large, stepwise extension of Skaftafell and Jökulsárgljúfur NPs [11]. The idea for a larger park in the Vatnajökull glacier realm had been raised and debated for a long time, with many of the contentions relating to conflicting interests in energy utilisation versus conservation [71]. It had a strong drive from the municipalities particularly in South Iceland with hopes to provide opportunities for rural development, and the decision to establish the park was made partially in reconciliation for the construction of the Kárahnjúkar hydropower plant east of the park boundary [71-74]. Parliament initiated the inquiry for the park in 1999 and a recommendation for the park was made in 2004 by the Parliamentary Committee. A working committee was established to deliberate on the park boundaries and management model in 2005. It worked until the dedicated park-specific Act 60/2007 [75] was passed and the park officially opened in 2008 [76]. The act provided a major change from its predecessors, Skaftafell and Jökulsárgljúfur NPs, that had been governed with a top-down governance structure, and transitioned towards an innovative co-management approach to governance that was designed as part of the planning and negotiation process and seen as a precondition for the park establishment by the local government actors [11].

These evolutionary trajectories that led to the establishment of the five PAs illustrate different timeframes, processes, power relations, conflicting interests and factors that directed and shaped their distinctive governance systems and available management options. What we also find is that the diverse and often protracted trajectories that shaped the five parks' creations have been able to become inclusive of local actors' interests and in general, they are therefore enjoying a high level of input legitimacy.

\subsection{The Different PA Governance Systems: A Comparative Institutional Analysis \\ 3.2.1. Pingvellir National Park (PNP)}

The site-specific legislation that formally outlines actor roles, mandates and institutional properties of the governance system for PNP was last updated through Act $47 / 2004$ [57]. It came with multiple changes such as an expanded area, objectives sharpened, the term National Park manifested and new measures for more effective management [77]. There have been further amendments of the legislation important for its governance since, especially in 2019 with new clauses that allowed the park to regulate commercial activities within the itself [78]. Pingvellir NP is an independent government agency that reported for a long time directly to the Prime Minister's Office but since 2017 to the Minister for Environment (Figure 3). The park's decision-making power is vested in the hands of the legally mandated Pingvellir Committee formed by seven members of Parliament, elected every 4 years in the beginning of the parliamentary term. The Pingvellir Committee appoints a Park Director responsible for executive decisions and day-to-day management with the head warden and interpretive manager. The legislation does not include roles of any other actors in park management and thus, is an example of a fully centralised PA governance system. Funding is administered directly from the state budget via the Ministry for Environment.

PNP has been an exceptionally popular tourism location and prior to COVID-19 it received around 1.5 million annual visitors. The visitor presence generated by these numbers, more than doubling from 696,000 in 2015 [79], in a relatively small area has become the single most important management challenge, manifested in several issues to handle such as parking, sewage, crowding, trampling etc. [80,81]. High visitor numbers have allowed the park to generate significant income from tourism fees; mainly from service provision and parking that provided around $80 \%$ of its overall income in 2019 [82]. This 
greatly aided the park during the tourism boom, but also created significant sustainability challenges as this revenue source diminished greatly during the COVID-19 pandemic.
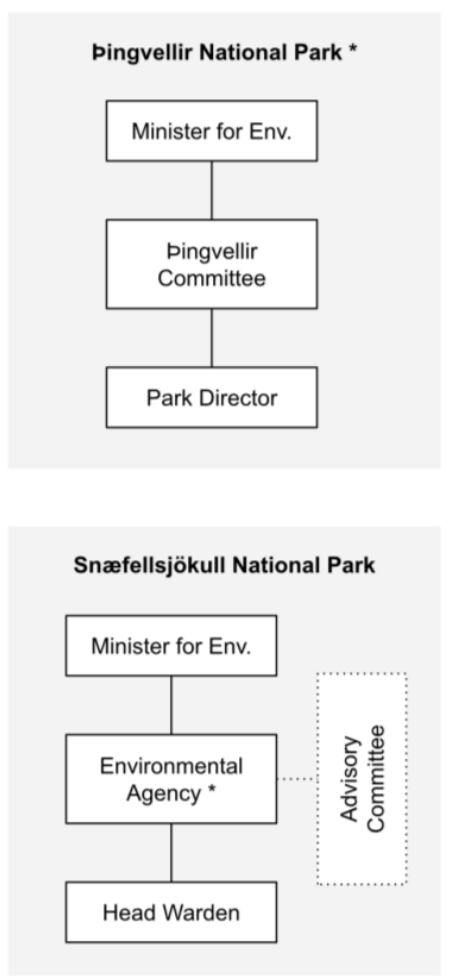
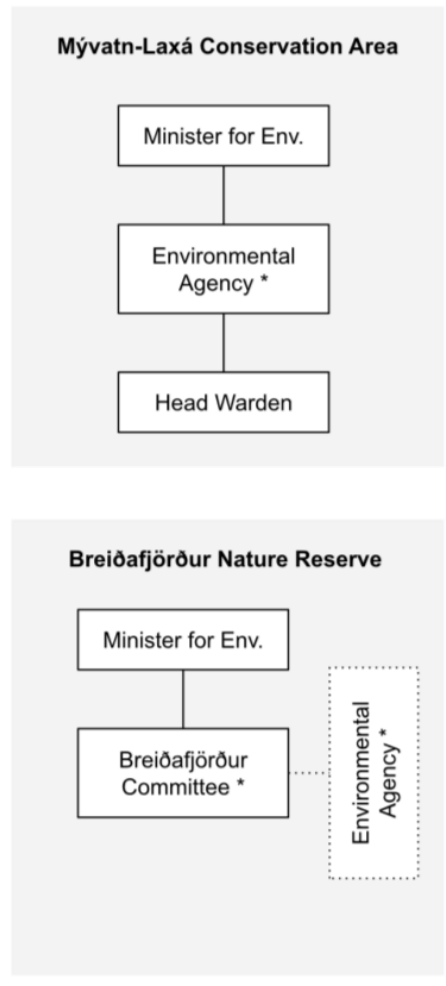

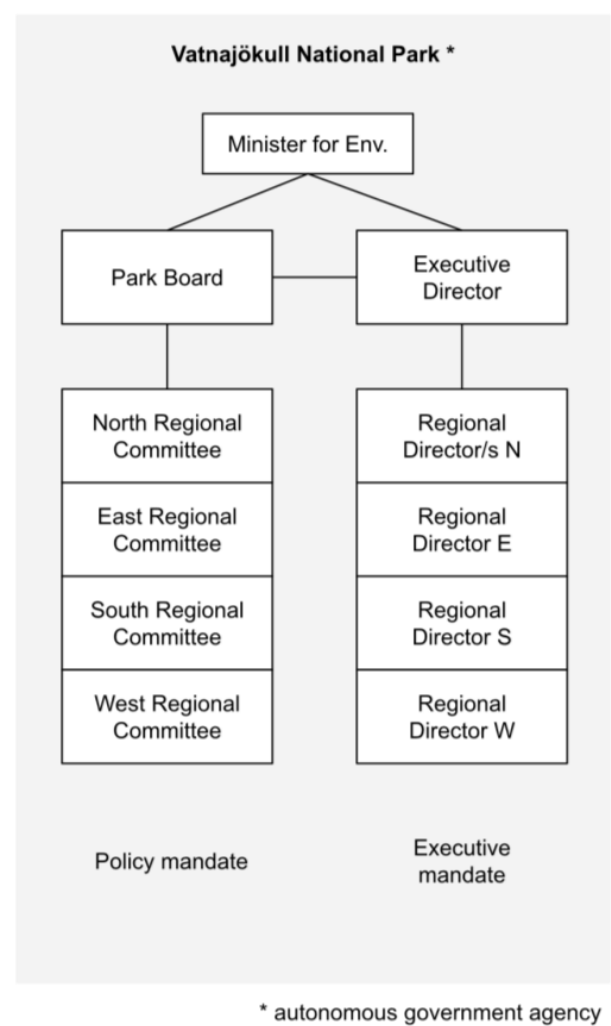

Figure 3. The governance system structures for the selected PAs (Vatnajökull NP [11]).

There is no legal requirement to create a management plan for PNP. However, the legislation requires the park to have a policy document, currently implemented as a vision and steering document [80], that functions as an updated management plan [83]. The policy goal ties closely with the idea of keeping Pingvellir as a shrine for Icelanders and the land as original as possible. This coincides with the top-down approach in the park governance system, and hence, does not require any direct involvement of other stakeholders in making the management plan. The current park administration has, however, responded to this by creating a broader consultation process in the making of the park vision that is inclusive of multiple stakeholders, and the park management also sees the importance of consultation through other non-PA specific public administration and good governance laws according to the interview data [83].

Our institutional analysis reveals that the PNP governance system has been adaptive and well fit to addressing upcoming management challenges, e.g., the boom in tourism. As the park's centralised governance system holds all executive and decision-making power and operates as an autonomous government agency with short command lines, it can respond to situations and needs quickly. According to a respondent [83], the park has been able to respond to the rapid increase of tourists by providing needed conservation infrastructure; it also pushed for the update of the legal framework to allow for more effective tourism management and enacted clauses that allowed the charging of the parking fees which now form a majority of its budget and help in paying for improved infrastructure and ranger services. These examples convey how the park can be managed effectively when it has a high profile and centralised management.

As made clear by our respondents, the PNP legal status and autonomy impacts greatly forces of institutional interplay. The park administration is powerful when interacting with other structures of governance, both within the central and local governments such as on issues of road construction and municipal spatial planning, to name but two [57]. PNP 
does maintain an active dialogue with the tourism industry and research institutions [83], but these are not legal obligations and these consultations operate more informally.

\subsubsection{Mývatn-Laxá Conservation Area (MLCA)}

The MLCA was established under site-specific legislation that sets the elements of its governance system, with the Environmental Agency (Umhverfisstofnun, abbr. EA) as the sole responsible government agency for managing the area (Figure 3). The legislation allows for the establishment of bylaws where rules concerning use and access restrictions can be established. The EA can also delegate management responsibilities to other parties according to the law on a contractual basis. Additionally, the law defines the scope of the Mývatn Research Station to conduct research and monitoring in the area as a government agency, however without a direct role in management of the park. The costs of running MLCA are covered from the state budget and funds are administered by the EA.

There is a legal mandate to create a management plan for MLCA, and there are requirements for a wide stakeholder consultation in its making, including the local governments, regional environmental NGOs and government agencies [84]. This creates an effective venue for more stakeholder inclusion, although the EA retains the lead executive power in the park's governance system. The current management plan provides a detailed list of specific activities and improvements, for example, indicating which areas should be accessible by footpaths and information and how certain areas should be protected, but otherwise lacks measures to manage visitor pressure [85]. Neither the legislation or management plan mention regulating commercial tourism activity-for example, permits can be issued only for resource-use purposes in the area-indicating how the governance system is still somewhat tied to its origins in the hydropower versus conservation conflict, and slow to incorporate challenges posed by commercial tourism.

However, the park bylaw was updated in 2012 [86] with more measures to limit traffic and visitor activity in the park. The bylaw also stipulates that further rules on traffic and tourist access can be set in the management plan. Additionally, as the MLCA makes use of the Nature Conservation Act (NCA) [36] when applicable on issues not set in its site-specific legislation. The NCA indirectly provides the park with measures for commercial tourism management, though this option has not yet been used. With the NCA and the new bylaw, the park management currently has the necessary measures to regulate tourism effectively in the area according to a respondent [87].

These updates suggest that the institutional fit of the MLCA governance system has improved significantly even though it remains somewhat complicated, drawing on indirect elements. The fact that the current management plan from 2011-2016 is long expired remains a sign of misfit. If a PA can be managed without the main planning tool for 5 years during the height of the tourism boom (and subsequent lull of the COVID-19 pandemic), it suggests the management plan has not been an effective tool. This became evident in an interview, where it was noted that the existing management plan had not been sufficiently practical, and the stakeholder engagement for the new management plan had been complicated and stalled the renewal process [87]. These are important findings related to horizontal and vertical interplay of the governance system, and in general, participatory PA management. Inclusive management and stakeholder participation are important for legitimacy in PA governance, but how it is being conducted matters. If the roles and responsibilities are not clearly set and agreed, there is a lack of trust or the ownership is unclear, the outcome can be compromised and lead the governance system to experience gaps in institutional fit and dysfunctional interplay.

\subsubsection{Breiðafjörður Nature Reserve (BNR)}

The site-specific legislation of BNR employs a local management approach to governance [66]. Its governance system puts mandate and powers in the hands of an independent management committee as the lead actor, the Breiðafjörður committee, reporting directly to the Minister for Environment (Figure 3). The municipalities must consult the Breiðafjörður 
Committee regarding spatial planning in the area. The Committee has seven members: four from local municipalities, one jointly from the Icelandic Institute of Natural History and the Nature Centre of West Iceland and West Fjords, one from the National Heritage Council and the chairperson appointed by the Minister. The EA has an advisory role to the Committee and may decide on some construction permits and resource-use licenses. There are limited provisions for park management in the legislation, but further bylaws are allowed. None have been set so far to regulate visitor activity or commercial tourism; however, the visitor numbers in the BNR are relatively low compared to the other case studies albeit not well-recorded. Funding for BNR is provided directly from the state budget, administered by the committee. The BNR funding is low, almost only to meet the cost of the committee members and their meetings.

There is a legal mandate to create a management plan for BNR, generated by the Breiðafjörður Committee in consultation with local municipalities, subject to approval by the Minister. The current management plan 2014-2019 [88] contains plans for protection of landscapes, geological formations, ecosystem and cultural heritage. It also aims to prepare the area for a growing number of tourists, increased research, and traditional utilisation of land and marine resources in the area. Economic activities (e.g., tourism, energy production, fishing, farming) and development projects are allowed as long as they do not contradict conservation values. Normally building permits are issued by the local municipalities, but projects outside of approved municipal spatial plans need to be approved by the EA. BNR's management plan contains several informative or educational actions to support tourism in the area but mentions no measures to manage tourism pressure though such protections are within the scope of the plan in the legislation. The Act on Breiðafjörður allows the Minister to issue regulations to restrict tourist access to vulnerable natural monuments in the PA on the Committees proposal, but this could be a slow way to respond to sudden pressures given the lack of other restriction measures in the management plan.

The Committee has executive power over the PA and is responsible for implementation of the management plan it creates, but it is not specified in the legislation who should do the day-to-day work. The Committee has only one part-time (25\%) employee taking care of administrative duties. The management plan envisages that Breiðafjörður should have a full-time ranger, but it took until 2019, almost 25 years after establishment, for the PA to get a part-time ranger service [53].

BNR does not have status as an autonomous government agency. Several spatial and temporal issues lead to question marks about whether the current governance setup is indeed fit to manage such a large area. The institutional fit of a governance system suffers if it is not defined or clear how to execute day-to-day management. Issues of vertical and horizontal interplay could also play a part here; the BNR seems disconnected from the other actors in the Icelandic PA governance system, lacking legally-enshrined cooperation structures e.g., with the EA.

Many of the issues related to weak executive capacity noted here have been recognised by the Breiðafjörður Committee. It opened a public dialog regarding the future of Breiðafjörður in 2019 and produced a report charting options for designations and changes in its operation [89]. The report acknowledges limited progress so far due to limited resources and lists six key points that need to be tackled when the legislation is updated, including establishment of permanent management staff and implementing stronger regulations regarding protection measures. Updating the management plan has been put on hold until the decisions regarding the future legislation are made.

\subsubsection{Snæfellsjökull National Park (SNP)}

The governance system of SNP is based on the NCA that otherwise defines most of Iceland's PAs, except those with site-specific legislation [36]. The Environmental Agency is the lead actor responsible for management of PAs, except for county parks that are run by local governments (Figure 3). Moreover, the EA can delegate its PA managerial role to other actors on a contractual basis apart from national parks. The NCA does not 
allow for direct sharing of powers in PA management, but for national parks it provides a legal basis for consultation committees for the head warden. The membership of those committees is limited to local governments, government authorities and NGOs in the fields of environment and tourism with a consultation role. The governance system for SNP is therefore highly centralised with the EA as a lead actor. It has also, with backing in the NCA and detailed in a bylaw [90], established a consultation committee that is active and meets on a regular basis, seeing the local government and other government agencies serving as members. Funding for SNP, as other PAs under the NCA (except for county parks), comes from the state budget via the EA.

The NCA demands all PAs to have management plans and sets out directions for the process of their development, contents and public participation. The SNP management plan has been formed by the EA in consultation with the Icelandic Institute for Natural History, municipality of Snæfellsbær and tourism operators [91]. The institutional arrangements in the current plan focus on infrastructure development and allow for the closure of areas to protect nature from tourism pressures. The management plan also allows the park to charge visitor fees to deal with damages from tourism. Following allowance for business activity licensing in the NCA, the management plan also mentions use of licensing to manage business activity, and the park has licensed activities such as cave and glacier tours to local tourism businesses.

We find the park provides a good institutional fit. The EA has the capacity and necessary frameworks for the protection of such areas. The NCA specifies management measures both for managing tourism pressure in terms of area closures and economic development in licensing models. According to our interviewee [92], the park management is content with the measures provided by the NCA and is also planning several soft ways to distribute tourism traffic during peak hours; additionally, high-frequency visitor days such as cruise ship visits to nearby towns are co-planned with local tourism providers. The SNP EGS is well-connected both vertically-with active interplay in the advisory committee to the local municipalities and tourism operators - and horizontally by collaboration with other PA governing institutions in Iceland-for example, by being the main organiser for the annual ranger course as mentioned in an interview [92].

\subsubsection{Vatnajökull National Park (VNP)}

The park-specific Act 60/2007 [75] of VNP defines a tailor-made co-management governance system, based on power sharing devolved to the local level (Figure 3). The park is an autonomous government agency that reports directly to the Minister, but the Minister's privileges are limited to chair and vice-chair nominations on the Park Board, approving the management plan and intervening only if measures in the plan are against laws. Its main decision-making authority is the Park Board with seven members: chairpersons of the four Regional Committees, one representative of environmental organisations, and the chair and vice-chair. The Park Board is responsible for park policy, budget, regulations, supervision, employment policy and coordination including the park's management plan. A Park Director is appointed by the Minister to hold executive decision-making power parallel to the board. Regional Committees operate each of four regions as independent business units, making decisions regarding local operations and preparing the regional management plans. Regional Committees have six members: three representatives from local municipalities, one from local tourism associations, one from outdoor recreation associations and one from environmental associations. Regional Managers are responsible for day-to-day operations in the regions (see [11]). The management plan for VNP is prepared by the Regional Committees and merged to a park-wide document by the Park Board. Funding for VNP is administered from the state treasury by the Ministry for Environment and the park also collects service fees set in a bylaw [93].

Institutional fit of VNP has benefited from its co-governance structure. Being a vast park with different regions in terms of natural attributes, populations, services and priorities, placing planning and decision making in the Regional Committees has provided 
necessary flexibility and allowed regional identities to emerge [11]. The park has been able to respond relatively effectively to the tourism pressure by facilitating legal and regulatory amendments allowing the park to regulate commercial tourism by requiring permits and licenses for commercial activities within the park [94]. The co-management structure has also effectively become a venue for vertical interplay between the local and central administrations [11]. The management plan is the central planning document for the park and the local government spatial plans need to be aligned to it; it consolidates the decisions to the higher administrative levels $[95,96]$. However, it was noted in the interview that the consolidation process was found to be very heavy and it was suggested that the park might dissect the whole park plan to regional management plans as a potentially speedier and more locally relevant solution [97].

In terms of horizontal interplay, the status of an autonomous park authority has provided the park with a raised platform nationally to highlight its issues and progress, and allowed it to lobby effectively for funds for park development following the ambitious objectives in its legal framework [11]. In comparison to parks under the NCA and EA, this is a special privilege. Another issue regarding horizontal interplay was raised in the interview: the park would like to regulate traffic on some roads within the park but under current legislation, this is not possible without taking full responsibility of the road management from the Road Authority [97]. Regarding vertical interplay, VNP has been efficient in coordinating the interaction between different decision-making levels due to its co-management structure [11].

Table 2 provides a synthesis and comparison of the key documents and management measures for the governance systems analysed in this chapter.

Table 2. Comparison of the governance setup for selected protected areas.

\begin{tabular}{|c|c|c|c|c|c|}
\hline & Pingvellir & Mývatn-Laxá & Breiðafjörður & Snæfellsjökull & Vatnajökull \\
\hline $\begin{array}{l}\text { Current governing } \\
\text { laws and bylaws }\end{array}$ & $\begin{array}{c}\text { Act } 47 / 2004 \text { on Pingvellir } \\
\text { NP [57], } \\
\text { updated by Act } 85 / 2019 \\
\text { [78], Bylaw } 848 / 2005[98]\end{array}$ & $\begin{array}{c}\text { Act } 97 / 2004 \text { on } \\
\text { Protection of Mývatn } \\
\text { and Laxá [84], Bylaw } \\
665 / 2012 \text { [86] }\end{array}$ & $\begin{array}{l}\text { Act 54/1995 on } \\
\text { Protection of } \\
\text { Breiðafjörður [66] }\end{array}$ & $\begin{array}{c}\text { Nature Conservation } \\
\text { Act 60/2013 [36], Bylaw } \\
935 / 2021 \text { [90] }\end{array}$ & $\begin{array}{c}\text { Act } 60 / 2007 \text { on } \\
\text { Vatnajökull NP } \\
\text { [75], updated by Act } \\
\text { 101/2016 [94], Bylaw } \\
\text { 300/2020 [99] }\end{array}$ \\
\hline Management type & Centralised & Centralised & $\begin{array}{l}\text { Locally managed by the } \\
\text { Breiðafjörður } \\
\text { Committee. }\end{array}$ & $\begin{array}{l}\text { Centralised with local } \\
\text { gov. involvement in } \\
\text { advisory role. }\end{array}$ & $\begin{array}{l}\text { Co-managed between } \\
\text { national and regional } \\
\text { gov. and civil society. }\end{array}$ \\
\hline $\begin{array}{l}\text { Responsible } \\
\text { organisations }\end{array}$ & $\begin{array}{l}\text { Parliament appoints } 7 \text { MPs } \\
\text { to Pingvellir Committee, } \\
\text { PNP park authority. }\end{array}$ & EA. & $\begin{array}{l}\text { The Breiðafjörður } \\
\text { Committee has } 7 \\
\text { members appointed by } \\
\text { the Minister. }\end{array}$ & $\begin{array}{c}\text { EA with an advisory } \\
\text { committee. }\end{array}$ & $\begin{array}{l}\text { National Park Board } \\
\text { with } 7 \text { members, } \\
\text { Regional Committees, } \\
\text { VNP park authority. }\end{array}$ \\
\hline $\begin{array}{l}\text { Day-to-day } \\
\text { operations }\end{array}$ & $\begin{array}{l}\text { Park Director, } \mathrm{PNP} \text { park } \\
\text { rangers. }\end{array}$ & $\begin{array}{l}\text { Head Warden, park } \\
\text { rangers by EA. }\end{array}$ & $\begin{array}{l}\text { Committee supervises, } \\
\text { no park management. }\end{array}$ & $\begin{array}{l}\text { Head Warden, park } \\
\text { rangers by EA. }\end{array}$ & $\begin{array}{l}\text { Park Director/ } \\
\text { Reg. managers, } \\
\text { VNP park rangers. }\end{array}$ \\
\hline $\begin{array}{c}\text { Current } \\
\text { management plan }\end{array}$ & $\begin{array}{c}\text { 2004-2024 [100], update } \\
\text { 2018-2038 [80] }\end{array}$ & 2011-2016 [85] & 2014-2019 [88] & 2010-2020 [101] & $\begin{array}{c}\text { 2011-2021 [95], update } \\
2013 \text { [96] }\end{array}$ \\
\hline $\begin{array}{l}\text { Management plan } \\
\text { formation and } \\
\text { approval }\end{array}$ & $\begin{array}{l}\text { Prepared by the park, } \\
\text { approved by Pingvellir } \\
\text { Committee. }\end{array}$ & $\begin{array}{l}\text { EA in consultation with } \\
\text { local authorities and } \\
\text { NGOs in the area, } \\
\text { approved by Minister. }\end{array}$ & $\begin{array}{c}\text { Breiðafjörður } \\
\text { Committee in } \\
\text { consultation with the } \\
\text { local municipalities, } \\
\text { approved by Minister. }\end{array}$ & $\begin{array}{l}\text { EA in consultation with } \\
\text { Icelandic Inst. of Nat. } \\
\text { History, local gov. and } \\
\text { tourism operators. } \\
\text { Approved by Minister. }\end{array}$ & $\begin{array}{l}\text { Regional Committees } \\
\text { prepare regional plans, } \\
\text { Board reviews and } \\
\text { merges to overall plan, } \\
\text { Minister approves. }\end{array}$ \\
\hline $\begin{array}{l}\text { Measures for } \\
\text { managing tourism } \\
\text { pressure }\end{array}$ & $\begin{array}{c}\text { Restricted motor traffic. } \\
\text { Visitors only on managed } \\
\text { footpaths. } \\
\text { Can issue penalties. }\end{array}$ & $\begin{array}{l}\text { Restrictions in traffic } \\
\text { and visitor access } \\
\text { allowed in bylaws. Can } \\
\text { issue penalties. }\end{array}$ & $\begin{array}{l}\text { Law allows for a bylaw } \\
\text { to define management } \\
\text { measures, but this has } \\
\text { not yet been issued. }\end{array}$ & $\begin{array}{l}\text { Restrictions in traffic } \\
\text { and visitor access } \\
\text { allowed in bylaws. Can } \\
\text { issue penalties. }\end{array}$ & $\begin{array}{l}\text { Damaged or threatened } \\
\text { areas may be } \\
\text { temporarily closed by } \\
\text { VNP. Can issue } \\
\text { penalties. }\end{array}$ \\
\hline $\begin{array}{l}\text { Measures for } \\
\text { commercial activity } \\
\text { management }\end{array}$ & $\begin{array}{l}\text { All business activities are } \\
\text { subject to license. The park } \\
\text { recognizes its role in } \\
\text { supporting economic } \\
\text { activities. }\end{array}$ & $\begin{array}{l}\text { EA can issue permits for } \\
\text { resource-use. } \\
\text { Commercial tourism } \\
\text { subject to permit } \\
\text { indirectly via NCA. }\end{array}$ & $\begin{array}{l}\text { Development projects in } \\
\text { general are allowed if } \\
\text { they do not risk } \\
\text { conservation values. }\end{array}$ & $\begin{array}{l}\text { All business activities } \\
\text { are subject to license. } \\
\text { Visitor fees can be } \\
\text { collected 'to limit or } \\
\text { repair damage caused } \\
\text { by tourists.' }\end{array}$ & $\begin{array}{l}\text { All business activities } \\
\text { are subject to license. } \\
\text { VNP may charge visitor } \\
\text { fees for services and } \\
\text { access to the area. }\end{array}$ \\
\hline
\end{tabular}




\subsection{The PA Governance Diversity and Its Multiple Implications}

When comparing the five PA governance systems and the trajectories of their establishment guided by the analytical framework, some important themes emerge.

The trajectories leading to the establishment of the five parks are all different; however, all involve long processes lasting many years where discussions of their important natural and cultural attributes revolve in public debate prior to a formal decision to establish the PAs. There can also be direct political drivers and motivations, seeing the park establishment as a reconciliation in conflicts around resource use, either as a trade-off relating to development versus conservation (VNP) or the PA as a measure to curb suggested development (MLCA).

These trajectories impact greatly what type of an EGS the respective PA gets. As we examine the links between the trajectories and EGS (see Figure 1) for the five parks, the following connections become apparent: The nationalistic and historical legacy factors contributed to PNP being granted status as an autonomous government agency, directed only by members of parliament in a top-down EGS management fashion, keeping the intergenerational connection between the old and contemporary Alpingi with a site-specific law. The conflicting trade-offs in the prelude to VNP between contested conservation versus energy utilisation resulted in a co-management EGS that was simply a precondition for the big park established at all and agreed upon by the local actors. Due to the grand scale of the park and need for detailed divisions of roles and mandates between park actorsits interplay with other land-use institutional arrangements-site-specific legislation was needed, which also granted VNP status as an autonomous government agency. The local initiative to establish BNR involving a careful transfer of power from landowners and local governments resulted in an EGS with a site-specific legislation and community-led park administration that has had limited institutional attributes capable of interfering with business-as-usual practice in the area. The lack of counterparts from actors on other levels in the community-only EGS seem to have resulted in a lack of facilitation of updates and progress. At Mývatn-Laxá, the political outcome to stop hydropower dam-building was incorporated within site-specific legislation halting such development as a primary objective but not allowing co-management. Finally, SNP was co-created by the central government and local actors over a long trajectory, characterised by low conflict and high level of trust, being the only NP in Iceland based on the general clauses in the NCA without any tailor-made solutions in its EGS. Interestingly, due to the high level of overall legitimacy at SNP, informal collaboration has taken place among park-related actors with planning and decision-making shared far beyond legal provisions. This comes as a deliberate attempt of co-management to share powers and increase legitimacy in the park management, although restricted by the general legislation.

The EGSs for the different parks—as different as they are-are generally well fit to meet their stated objectives according to our analysis and more importantly, have proven to be adaptive to address emerging management challenges as they rise. It would be difficult to draw the conclusion that one EGS is superior to another; they all have their strengths and weaknesses. Some of these strengths/weaknesses are embedded in the governance systems, hence the duality that a particular EGS will typically have particular challenges. Looking at some of these dualities, we see that a co-managed EGS (VNP) suffers from lengthy and complex decision/command lines but amplifies legitimacy at the output level with its high level of actor inclusion and adaptability. The top-down model of EGS (PNP) is more lean-and-mean and allows for quick management responses but has lower output legitimacy due to lack of inclusion in its planning and decision making. Lastly, placing only community actors in the lead of PA EGS (BNR) suffers from being side-lined in competing for funding and risks not being heard. These observations add to the discussion on evolving park governance and the applicability of different governance types and systems [9,15].

There are no panaceas when designing EGS for protected areas; instead, there is a need for a nuanced understanding of their context-dependent nature and capacity to adapt. Rejecting panaceas is well documented in the institutional literature $[45,102]$, but needs to 
be constantly reiterated to counter the drive for blueprint, straight-jacketed governance solutions. This is an important lesson also from our study, and it might require site-specific legislation to accommodate all necessary interests. Looking beyond the individual parkmanagement level, however, such EGS fragmentation and diversity can constitute multiple challenges at the national level. This can relate to the development of a coherent, effective national system of PAs [103], to economic actors and park users, and on the development and expectations during the creation of new PAs.

This calls therefore upon strong policy guidance with more robust structures than only informal park-to-park exchanges. In the case of Iceland, the measures for this might come as a merger of the agencies into a park service commonly found elsewhere, or a legislative and policy update that would allow and embrace PA governance diversity but secure more coordinated measures for their day-to-day management. The need for a stronger shared vision across the PAs and means of sharing knowledge and capacity was also brought up by an interviewee [92]. The current portfolio of PA governance systems accommodates most of the needed attributes and measures, but a key problem is its scattered form and locked-in individual governance systems that do not support coordinated action.

\subsection{Wider Implications of the Findings}

This study adds to and expands the growing literature on PA governance systems worldwide (e.g., [11,104-108]), and aids in the more detailed understanding of their diversity, beyond the classic 'centralized-, private-, indigenous- and co-managed management' typology [15]. The growing scholarship in institutional analysis has generated multiple frameworks to allow for analysis of governance systems, recalling our application of the EGS framework but also Ostrom's Institutional Analysis and Development (IAD) and various Social-Ecological Systems (SES) frameworks $[2,45,109]$. These are jointly advancing the study of how the large and growing PA estate can be governed towards sustainable outcomes. This is utterly important; more 'paper parks' is not the aim of the growing global aspiration for more park coverage, but parks that are well-governed, equitable, inclusive, and adaptive in their approach to management $[15,110,111]$.

This study contributes to deeper understanding of PA governance, being novel to the Icelandic park estate and beyond, by providing an original adoption of the general EGS frameworks to the case of PAs that we find well suited for advancing a nuanced analysis of their governance systems. Our adoption moves beyond an understanding of a park EGS as static by placing the framework in an evolutionary context of the park establishment trajectory and the understanding of their adaptability to change. In an uncertain future, learning from the past truly applies for parks.

The multiple global environmental changes of our era are driving park expansion (e.g., [112,113]). Our novel analysis shows how intricately the institutional park setup is linked to the historical origins and establishment trajectories of each PA. Understanding the context and including the stakeholders in the negotiations was a key factor for legitimacy of the Icelandic PAs during their establishment, coinciding with other studies (e.g., [114-116]), and an important reminder for the future as countries expand their PA estates and strive towards new conservation targets $[25,26,117]$. For the future, we see further opportunities in advancing the study of PA governance systems and their dynamics, especially on the park governance systems' adaptive management capacity (e.g., [118-120]) and resilience (e.g., $[121,122])$.

\section{Conclusions}

Within Iceland's PA estate, we find a great diversity in governance systems, both in park actor structures and institutional arrangements. This has not come by chance, however. Our analysis of their establishment trajectories reveals how the different PAs were suggested and negotiated, and the key features of their governance systems deliberately outlined in formal legal frameworks. This partly results in these major parks in the country enjoying high input legitimacy, hence their establishment phase is generally perceived as legitimate. 
For this study, we developed an environmental governance system (EGS) framework purposely for PA analysis, based on the well-established scholarships in institutional analysis and governance $[2,44,45]$. We find this framework useful and effective for conceptualization and analysis of defining factors of PA governance systems and applicable beyond this study.

Our analysis of the individual PA governance systems shows that their initial trajectories greatly shape their attributes and that there is an attempt to tailor solutions to the differences in the PA social context. This has surely been a vehicle to secure their legitimacy at the input level. Recalling Ostrom's [45] strong argument, there are no "panaceas" when creating governance systems for PAs at their initial stage as our analysis has disclosed. Such PA diversity can be embraced as a sign of an effective approach to governance instead of trying to fit all into singular, blueprint-based solutions.

This diverse approach to governance has however come with its challenges, in particular concerning their fitness to effectively manage and adapt to challenges that can put their conservation values and sustainability at stake. In the Icelandic case, the boom in tourist numbers-from a stable 500,000 annually in 2010 rising to 2.5 million in 2018 - has been such an abrupt challenge for a nation with a population of less than 400,000 . We found the PA governance systems in the study initially lacking effective legal measures for management, but multiple adaptations have been implemented since to address this. We find the co-managed governance system in Vatnajökull NP to be the most adaptive and pioneering in developing its institutional framework to more effectively cope with the rapidly growing tourism. This is facilitated by the co-management aspect; hence, adaption of the governance system to changes is not a sole mandate of any single actor level, but requires multi-level action that we find is delivered by the co-management model. This has, however, also enabled other Icelandic parks to follow and adapt their EGSs.

What we find as an obvious drawback of this diversity is its lack of coordination and dispersed park administration capacity. As a consequence of site-specific legislation, the PA estate has become somewhat scattered with the decision-making powers and mandates spread across independent PA administrations and the Environmental Agency. Equally, the executive power and day-to-day management capacity is spread between different administrations. This risks overlapping roles and replication of labour, and can manifest in skill and capacity gaps.

Following our analysis, our main policy recommendations are that allowing for PA governance system diversity and site-specific arrangements can be essential to facilitate legitimacy of the areas, manifested at the input level during their establishment stage. Site-specific legislations and administrations can, however, be counterproductive and negatively impact their legitimacy at the output level, as the diversity may lack structures for coordination as our respondents stated, and result in underperformance due to flaws in the governance systems and lack of capacity within each park unit.

There is a necessity to secure coordination and coherence between the diverse PA systems in order to secure their capacity and fitness to meet diverse governance challenges, as Iceland's booming tourism sector has exposed. In the case of Iceland, this could be achieved with a merger of the agencies into a park service allowing governance diversity but securing a stronger shared vision, greater capacity and more coordinated measures in day-to-day management.

These implications are important for Iceland and beyond as it seeks to continue expanding its PA area estate and provide effective and equitable governance, capable of adapting to emerging management challenges.

\section{Endnotes}

We use a generic expression of Minister/Ministry for Environment to refer to the Minister/Ministry in charge of protected areas. 
Author Contributions: Conceptualization, J.G.P. and J.S.; data curation, J.S. and J.G.P., funding acquisition, J.S. and J.G.P.; methodology, J.S. and J.G.P.; formal analysis, J.S. and J.G.P.; investigation, J.S. and J.G.P.; writing-original draft preparation, J.S.; writing-review and editing, J.S., J.G.P., D.C. and B.D.; supervision, J.G.P. All authors have read and agreed to the published version of the manuscript.

Funding: This research funded by a PhD grant from University of Iceland Research Fund.

Institutional Review Board Statement: Not applicable.

Informed Consent Statement: Not applicable.

Data Availability Statement: Not applicable.

Acknowledgments: We would like to thank Michaël Bishop for the GIS work on the map concerning the selected Icelandic PAs.

Conflicts of Interest: The authors declare no conflict of interest.

\section{Appendix A}

Outline of the guiding questions for in-depth interviews with park managers:

- Do the current Acts and bylaws that define governance of your protected area provide you with necessary legal tools for effective tourism management? If not, what amendments to the law or bylaws would you see necessary?

- Is the management plan a useful tool for your protected area regarding visitor management? How are you using it (if any) to support visitor management?

- Who are your most important stakeholders regarding park management? How do your interactions with them support governing the park?

\section{References}

1. Ostrom, E. Background on the institutional analysis and development framework. Policy Stud. J. 2011, 39, 7-27. [CrossRef]

2. Vatn, A. Environmental Governance: Institutions, Policies and Actions; Edward Elgar Publishing: Cheltenham, UK, $2015 ;$ p. 464.

3. UNEP-WCMC \& IUCN. Protected Planet: The World Database on Protected Areas (WDPA) and World Database on Other Effective Area-based Conservation Measures (WD-OECM). 2022. Available online: https://www.protectedplanet.net/en (accessed on 6 January 2022).

4. Watson, J.E.; Dudley, N.; Segan, D.B.; Hockings, M. The performance and potential of protected areas. Nature 2014, 515, 67-73. [CrossRef] [PubMed]

5. IUCN. Protected Area Categories. Available online: https://www.iucn.org/theme/protected-areas/about/protected-areacategories (accessed on 6 January 2022).

6. IUCN. The Natural Resource Governance Framework: Improving Governance for Equitable and Effective Conservation; IUCN: Gland, Switzerland, 2021.

7. Coad, L.; Watson, J.E.; Geldmann, J.; Burgess, N.D.; Leverington, F.; Hockings, M.; Knights, K.; Di Marco, M. Widespread shortfalls in protected area resourcing undermine efforts to conserve biodiversity. Front. Ecol. Environ. 2019, 17, 259-264. [CrossRef]

8. Leverington, F.; Costa, K.L.; Pavese, H.; Lisle, A.; Hockings, M. A global analysis of protected area management effectiveness. Environ. Manag. 2010, 46, 685-698. [CrossRef] [PubMed]

9. Hutton, J.; Adams, W.M.; Murombedzi, J.C. Back to the barriers? Changing narratives in biodiversity conservation. Forum Dev. Stud. 2005, 32, 341-370. [CrossRef]

10. Borrini, G.; Kothari, A.; Oviedo, G. Indigenous and Local Communities and Protected Areas: Towards Equity and Enhanced Conservation: Guidance on Policy and Practice for Co-Managed Protected Areas and Community Conserved Areas; IUCN: Gland, Switzerland, 2004; p. 112.

11. Petursson, J.G.; Kristofersson, D.M. Co-Management of Protected Areas: A Governance System Analysis of Vatnajökull National Park, Iceland. Land 2021, 10, 681. [CrossRef]

12. Naughton-Treves, L.; Holland, M.B.; Brandon, K. The role of protected areas in conserving biodiversity and sustaining local livelihoods. Annu. Rev. Environ. Resour. 2005, 30, 219-252. [CrossRef]

13. Maxwell, S.L.; Cazalis, V.; Dudley, N.; Hoffmann, M.; Rodrigues, A.S.; Stolton, S.; Visconti, P.; Woodley, S.; Kingston, N.; Lewis, E. Area-based conservation in the twenty-first century. Nature 2020, 586, 217-227. [CrossRef]

14. Bennett, N.J.; Di Franco, A.; Calò, A.; Nethery, E.; Niccolini, F.; Milazzo, M.; Guidetti, P. Local support for conservation is associated with perceptions of good governance, social impacts, and ecological effectiveness. Conserv. Lett. 2019, 12, e12640. [CrossRef] 
15. Borrini, G.; Dudley, N.; Jaeger, T.; Lassen, B.; Neema, P.; Phillips, A.; Sandwith, T. Governance of Protected Areas: From Understanding to Action; Best practice protected area guidelines series; IUCN: Gland, Switzerland, 2013.

16. Berkes, F. Evolution of co-management: Role of knowledge generation, bridging organizations and social learning. J. Environ. Manag. 2009, 90, 1692-1702. [CrossRef]

17. Young, O.R. The Institutional Dimensions of Environmental Change: Fit, Interplay, and Scale; MIT Press: Cambridge, MA, USA, 2002; p. 221.

18. Phillips, A. Economic Values of Protected Areas: Guidelines for Protected Area Managers, Task Force on Economic Benefits of Protected Areas of the WCPA of IUCN in Collaboration with the Economics Service Unit of IUCN; IUCN: Gland, Switzerland, 1998.

19. Buongiorno, A.; Intini, M. Sustainable tourism and mobility development in natural protected areas: Evidence from Apulia. Land Use Policy 2021, 101, 105220. [CrossRef]

20. Breiby, M.A.; Selvaag, S.K.; Øian, H.; Duedahl, E.; Lerfald, M. Managing sustainable development in recreational and protected areas. The Dovre case, Norway. J. Outdoor Recreat. Tour. 2022, 37, 100461. [CrossRef]

21. Järv, H.; Ward, R.D.; Raet, J.; Sepp, K. Socio-Economic Effects of National Park Governance and Management: Lessons from Post-Socialist Era Estonia. Land 2021, 10, 1257. [CrossRef]

22. Dudley, N.; Stolton, S. PROTECTED AREAS: Challenges and responses for the coming decade. Equilibrium Research Dialogue: Bristol, UK, 2018; Volume 1.

23. Storrank, B.; Turunen, T. Protected Areas and Sustainable Rural Development; Nordic Council of Ministers: Copenhagen, Dembark, 2006.

24. Fredman, P.; Margaryan, L. 20 years of Nordic nature-based tourism research: A review and future research agenda. Scand. J. Hosp. Tour. 2021, 21, 14-25. [CrossRef]

25. European Commission. Communication from the Commission to the European Parliament, the Council, the European Economic and Social Committee and the Committee of the Regions. EU Biodiversity Strategy for 2030-Bringing Nature back into our Lives; COM(2020); European Commission: Brussels, Belgium, 2020.

26. Convention on Biological Diversity. Update of the Zero Draft of the POST-2020 Global Biodiversity Framework. CBD/POST2020/PREP/2/1; Secretariat of the Convention on Biological Diversity: Montreal, QC, Canada, 17 July 2020.

27. Ritchie, H.; Roser, M. Our World in Data-Land Use. Available online: https://ourworldindata.org/land-use (accessed on 27 January 2022).

28. Petursson, J.G.; Thorvardardottir, G.; Crofts, R. Developing Iceland's Protected Areas: Taking Stock and Looking Ahead. Parks 2016, 22. [CrossRef]

29. Rögnvaldsdóttir, L. Economic Effects of Tourism in Pingeyjarsýslur; Icelandic Tourism Research Centre: Akureyri, Iceland, 2016; ISBN 978-9935-437-45-7.

30. Siltanen, J. Economic Impact of Iceland's Protected Areas and Nature-Based Tourism Sites; Institute of Economic Studies: Reykjavík, Iceland, 2018.

31. Sorrell, E.; Plante, A.F. Dilemmas of Nature-Based Tourism in Iceland. Case Stud. Environ. 2021, 5, 964514. [CrossRef]

32. Statistics Iceland. Population by Municipality, Sex, Citizenship and Quarters 2010-2021. Available online: https:/ / px.hagstofa.is: 443/pxen/sq/7c798dfb-245d-42f3-84b8-14d4965673d2 (accessed on 17 January 2022).

33. Statistics Iceland. Several Geographical Data. Available online: https://px.hagstofa.is:443/pxen/sq/d4b70bc2-65b8-471a-b12f89acdec726a2 (accessed on 17 January 2022).

34. European Environmental Agency. Land Use-State and Impacts (Iceland). 2010. Available online: https:/ / www.eea.europa.eu/ soer/2010/countries/is/land-use-state-and-impacts-iceland (accessed on 6 January 2022).

35. Environmental Agency of Iceland. Ársskýrsla Umhverfisstofnunar 2020 (Trans. Environmental Agency Annual Report 2020). Available online: https:/ / arsskyrsla.ust.is/2020/ (accessed on 6 January 2022).

36. Icelandic Parliament. 60/2013 Lög um Náttúruvernd (Trans. Act on Nature Protection). Available online: https:/ / www.althingi. is/lagas/nuna/2013060.html (accessed on 6 January 2022).

37. Bogason, Á.; Karlsdóttir, A.; Brandt Broegaard, R.; Jokinen, J.C. Planning for Sustainable Tourism in the Nordic Rural Regions: Cruise Tourism, the Right to Roam and Other Examples of Identified Challenges in a Place-Specific Context. Nordregio: Stockholm, Sweden, 2021; Volume 81. [CrossRef]

38. Sæpórsdóttir, A.D.; Saarinen, J. Challenges due to changing ideas of natural resources: Tourism and power plant development in the Icelandic wilderness. Polar Record 2016, 52, 82-91. [CrossRef]

39. Burns, G.L.; Haraldsdóttir, L. Hydropower and tourism in Iceland: Visitor and operator perspectives on preferred use of natural areas. J. Outdoor Recreat. Tour. 2019, 25, 91-101. [CrossRef]

40. Voegeli, G.; Finger, D.C. Disputed dams: Mapping the divergent stakeholder perspectives, expectations, and concerns over hydropower development in Iceland and Switzerland. Energy Res. Soc. Sci. 2021, 72, 101872. [CrossRef]

41. Icelandic Tourist Board. Tourism in Iceland in Figures. Available online: https://www.ferdamalastofa.is/en/recearch-andstatistics/tourism-in-iceland-in-figures (accessed on 6 January 2022).

42. Sæpórsdóttir, A.D.; Hall, C.M.; Wendt, M. From boiling to frozen? The rise and fall of international tourism to Iceland in the era of overtourism. Environments 2020, 7, 59. [CrossRef]

43. Icelandic Chamber of Commerce. The Icelandic Economy Q4 2021—Current State, Recent Developments and Future Outlook. Available online: https:/ / www.chamber.is/reports/icelandic-economy-q42021 (accessed on 6 January 2022). 
44. Ostrom, E. Governing the Commons: The Evolution of Institutions for Collective Action; Cambridge University Press: Cambridge, $\mathrm{UK}, 1990$.

45. Ostrom, E. A diagnostic approach for going beyond panaceas. Proc. Natl. Acad. Sci. USA 2007, 104, 15181-15187. [CrossRef] [PubMed]

46. Kooiman, J.; Bavinck, M.; Chuenpagdee, R.; Mahon, R.; Pullin, R. Interactive governance and governability: An introduction. J. Transdiscipl. Environ. Stud. 2008, 7, 1-11.

47. Bäckstrand, K. Multi-stakeholder partnerships for sustainable development: Rethinking legitimacy, accountability and effectiveness. Eur. Environ. 2006, 16, 290-306. [CrossRef]

48. Scharpf, F.W. Governing in Europe: Effective and Democratic? Oxford University Press: Oxford, UK; New York, NY, USA, 1999; p. 252.

49. Young, O.R.; King, L.A.; Schroeder, H. Institutions and Environmental Change: Principal Findings, Applications, and Research Frontiers; MIT Press: Cambridge, MA, USA, 2008.

50. Ekstrom, J.A.; Young, O.R. Evaluating functional fit between a set of institutions and an ecosystem. Ecol. Soc. 2009, 14, 16. [CrossRef]

51. Guicharnaud, R.A.; Jóhannsdóttir, S.S.; Vilmundardóttir, O.K.; Sigurðsson, I.A.; Stefánsson, R.A.; Unnsteinsdóttir, E.; Snæpórsson, A.Ö.; Óskarsdóttir, G. Aðferðir við Vöktun Náttúruverndarsvæða—Handbók (trans. Methods for Monitoring Nature Reserves—Handbook); Icelandic Institute of Natural History: Garðabær, Iceland, 2021.

52. Green, B.N.; Johnson, C.D.; Adams, A. Writing narrative literature reviews for peer-reviewed journals: Secrets of the trade. J. Chiropr. Med. 2006, 5, 101-117. [CrossRef]

53. Environmental Agency of Iceland. Landvarsla við Breiðafjörð 2020 (Trans. Ranger Report from Breiðafjörður 2020). Available online: https:/ / ust.is/library/sida/Nattura/Landvarsla\%20vi\%c3\%b0\%20Brei\%c3\%b0afj\%c3\%b6r\%c3\%b0\%202020.pdf (accessed on 6 January 2022).

54. Pórðarson, M. Verndun fagurra staða og merkja náttúrumenja (trans. Protection of beautiful places and natural monuments). In Skírnir; Hið Íslenska Bókmenntafélag: Reykjavík, Iceland, 1907; Volume 81, pp. 180-182.

55. Davíðsson, G. Pingvellir við Öxará (trans. Pingvellir by Oexara river). In Eimreiðin; Kaupmannahöfn: Copenhagen, Denmark, 1913; Volume 19, pp. 210-216.

56. Icelandic Parliament. 59/1928 Lög um friðun Pingvalla (Trans. Act on Protection of Pingvellir). Available online: https: //www.althingi.is/lagas/130a/1928059.html (accessed on 15 January 2022).

57. Icelandic Parliament. 47/2004 Lög um pjóðgarðinn á Pingvöllum (Trans. Act on Pingvellir National Park). Available online: https: / / www.althingi.is/lagas/nuna/2004047.html (accessed on 6 January 2022).

58. Karlsdóttir, U.B. Par sem fossarnir falla: Náttúrusýn og nýting fallvatna á Íslandi 1900-2008 (trans. Where the waterfalls fall: Nature experience and utilization of waterfalls in Iceland 1900-2008); Hið íslenska Bókmenntafélag: Reykjavík, Iceland, 2010.

59. Olafsson, H. A True Environmental Parable: The Laxá-Mývatn Conflict in Iceland, 1965-1973 An Ecological and Anthropological Approach. Environ. Rev. 1981, 5, 2-38. [CrossRef]

60. Environmental Agency of Iceland. Viðaukar við verndaráætlun Mývatns og Laxár (Trans. Appendices to the Management Plan of Mývatn and Laxá). Available online: http://vatn.is/library/Skrar/Einstaklingar/Nattura/Verndaraaetlanir/vi\%C3\%B0 aukar\%20vi\%C3\%B0\%20verndar\%C3\%A1\%C3\%A6tlun\%20M\%C3\%BDvatns\%20og\%20Lax\%C3\%A1r_www.pdf (accessed on 27 January 2022).

61. Gizurarson, S. Laxárdeilan. Lögmaður Landeigenda Segir frá (trans. The Laxá River Dispute. Landowners Lawyer Speaks out); Skákprent: Reykjavík, Iceland, 1991.

62. Icelandic Parliament. 35. Tillaga (1992) til Pingsályktunar um Verndun og Könnun á Lífríki Breiðafjarðar (Trans. Proposal for a Parliamentary Resolution on the Protection and Survey of the Ecosystem of Breiðafjörður). Available online: https: //www.althingi.is/altext/100/s/pdf/0035.pdf (accessed on 18 January 2022).

63. Icelandic Parliament. 566/117 (1993) Frumvarp til Laga um vernd Breiðafjarðar (Trans. Proposal on the Protection of Breiðafjörður). Available online: https:/ / www.althingi.is/altext/117/s/0566.html (accessed on 18 January 2022).

64. Pórðarson, F. Vernd Breiðafjarðar (trans. Protection of Breiðafjörður). In Breiðfirðingur; Steindórsprent-Gutenberg: Reykjavík, Iceland, 1996; Volume 54, pp. 129-145.

65. Pagnan, J. Protected Areas of the Arctic: Conserving a Full Range of Values. 2002. Available online: https://oaarchive.arcticcouncil.org/handle/11374/173 (accessed on 6 January 2022).

66. Icelandic Parliament. 54/1995 Lög um vernd Breiðafjarðar (Trans. Act on the Protection of Breiðafjörður). Available online: https:/ / www.althingi.is/lagas/nuna/1995054.html (accessed on 6 January 2022).

67. Sigurðsson, S.J.; Óttarsson, Á.; Jónasson, K.; Porvarðardóttir, G.; Jóhannsson, P.S. Pjóðgarðurinn Snæfellsjökull—Skýrsla Starfshóps um Stofnun pjóðgarđs á Snæfellsnesi til ráoherra í júní 2001 (trans. Snæfellsjökull National Park-Report of a Working Group on the Establishment of a National Park in Snæfellsnes to the Minister in June 2001); Pjóðgarðurinn Snæfellsjökull: Snæfellsbær, Iceland, 2001.

68. Böðvarsson, S.; Eiríksson, M.; Alexandersson, S.; Björnsdóttir, M.B.; Elinbergsson, S. Djóðgarður á utanverðu Snæfellsnesi. Lokaskýrsla; Preparatory Committee for National Park in Snæfellsness: Snæfellsbær, Iceland, 1997.

69. Snæfellsjökull National Park. Afmælisrit Pjóðgarðsins Snæfellsjökuls 2021 (Trans. Anniversary Book of Snæfellsjökull National Park). Available online: https://ust.is/library/sida/Nattura/thjodgardurinn.snaefellsjokull.afmaelisrit.2021.x.pdf (accessed on 6 January 2022). 
70. Porláksson, H. bjóðgarður undir Jökli - Um sögukafla fyrir verndaráxtlun (trans. National park under the glacier - Historical review for protection); Undirbúningsnefnd fyrir pjóðgarð á utanverðu Snæfellsnesi (trans. Preparation Committee for a National Park Outside Snæfellsnes): Reykjavík, Iceland, 1997.

71. Gunnarsson, A. Orðræða um stofnun Vatnajökulspjóðgarðs. Ferðamennska, sjálfbærni og samfélag (trans. Discourse on the Establishment of Vatnajökull National Park. Tourism, Sustainability and Society); University of Iceland: Reykjavík, Iceland, 2010.

72. Benediktsson, K.; Porvarðardóttir, G. Frozen opportunities?: Local communities and the establishment of Vatnajökull National Park Iceland. In Mountains of Northern Europe: Conservation, Management, People and Nature; Thompson, D.B., Price, M.F., Galbraith, C.A., Eds.; The Stationery Office (TSO): London, UK, 2005; Volume 13, pp. 335-348.

73. Gunnarsson, S.B. Vatnajökulspjóðgarður (trans. Vatnajökull National Park). In Glettingur; Útgáfufélag Glettings: Egilsstaðir, Iceland, 2007; Volume 44, pp. 26-30.

74. Feingold, M. The Political Ecology of Protected Areas: The Case of Vatnajökull National Park; University of Iceland: Reykjavík, Iceland, 2021.

75. Icelandic Parliament. 60/2007 Lög um Vatnajökulspjóðgarð (Trans. Act on Vatnajökull National Park). Available online: https: / / www.althingi.is/lagas/nuna/2007060.html (accessed on 6 January 2022).

76. Baldursson, S.; Guðnason, J.; Hannesdóttir, H.; Pórðarson, P. Nomination of Vatnajökull National Park: Dynamic nature of fire and ice for inclusion in the World Heritage List; Vatnajökull National Park: Reykjavík, Iceland, 2018.

77. Icelandic Parliament. 1326/130 Frumvarp til laga um pjóðgarðinn á Pingvöllum (Trans. Proposal for law on Pingvellir National Park). Available online: https:/ / www.althingi.is/altext/130/s/1326.html (accessed on 6 January 2022).

78. Icelandic Parliament. 85/2019 Lög um Breytingu á lögum um pjóðgarðinn á Pingvöllum, nr. 47/2004, með síðari Breytingum: Samningar við pjónustuaðila (Trans. Act Amending the Act on Pingvellir National Park, with Subsequent Amendments: Agreements with Service Providers). Available online: https://www.althingi.is/altext/stjt/2019.085.html (accessed on 15 January 2022).

79. Pingvellir National Park. Pjóðgarðurinn á Pingvöllum—Starfsskýrsla 2013-2016 (Trans. Pingvellir National Park—Annual Report 2013-2016). Available online: https:/ / www.thingvellir.is/media/1518/thingvellir_skyrsla_mars_2017_72.pdf (accessed on 22 January 2022).

80. Pingvellir National Park. Stefnumörkun Pingallapjóðgarðs 2018-2038 (Trans. Strategic Plan of Pingvellir National Park 2018-2038). Available online: https:/ / www.thingvellir.is/media/1754/a1072-023-u02-stefnumorkun-vefur.pdf (accessed on 6 January 2022).

81. Sigurjónsdóttir, J.K. Pingvellir til framtíðar: Álagsmat í pjóðgarðinum á Pingvöllum (trans. An Assessment of Visitor Pressure at Pingvellir National Park). Master's Thesis, Agricultural University of Iceland, Hvanneyri, Iceland, 2021.

82. Pingvellir National Park. Ársreikningur 2019 (Trans. Annual Accounts 2019). Available online: https://www.thingvellir.is/ media/1958/14216-thjodgardurinn-a-thingvoellum-arsreikningur-2019.pdf (accessed on 6 January 2022).

83. Siltanen, J. (University of Iceland, Reykjavík, Iceland). Interview with respondent 1. Personal Communication, 2022.

84. Icelandic Parliament. 97/2004 Lög um verndun Mývatns og Laxár í Suður-Pingeyjarsýslu (Trans. Act on Protection of Mývatn and Laxá in South-Pingeyjarsýsla). Available online: https:/ / www.althingi.is/lagas/nuna/2004097.html (accessed on 6 January 2022).

85. Environmental Agency of Iceland. Mývatn og Laxá Verndaráætlun 2011-2016 (Trans. Mývatn and Laxá Management Plan 2011-2016). Available online: https://ust.is/library/Skrar/Einstaklingar/Fridlyst-svaedi/Fridlysingar/verndar\%c3\%a1\%c3 \%a6tlun \%20M\%c3\%bdvatns\%20og\%20Lax\%c3\%a1r-www.pdf (accessed on 27 January 2022).

86. Icelandic Ministry of Environment. 665/2012 Reglugerð um verndun Mývatns og Laxár í Suður-Pingeyjarsýslu (Trans. Regulation on the Protection of Lake Mývatn and Laxá in South-Pingeyjarsýsla). Available online: https://island.is/reglugerdir/nr/0665-2 012 (accessed on 15 January 2022).

87. Siltanen, J. (University of Iceland, Reykjavík, Iceland). Interview with respondent 3. Personal Communication, 2022.

88. Breiðafjörður Committee. Verndaráætlun fyrir Breiðafjörð: 2014-2019 (trans. Management Plan for Breiðafjörður 2014-2019); Breiðafjarðarnefnd: Stykkishólmur, Iceland, 2014.

89. Breiðafjörður Committee. Framtíð Breiðafjarðar-Samantekt og niðurstöður Breiðafjarðarnefndar (trans. The Future of BreiðafjörðurSummary and Conclusions of the Breiðafjörður Committee); Breiðafjarðarnefnd: Stykkishólmur, Iceland, 2021; p. 119.

90. Icelandic Ministry of Environment and Natural Resources. 935/2021 Auglýsing um friðlýsingu Pjóðgarðsins Snæfellsjökuls (Trans. Announcement Regarding the Protection of Snæfellsjökull National Park). Available online: https://ust.is/library/sida/Nattura/ Regluger\%c3\%b0\%20um\%20\%c3\%9ej\%c3\%b3\%c3\%b0gar\%c3\%b0inn\%20Sn\%c3\%a6fellsj\%c3\%b6kul\%202021.pdf (accessed on 15 January 2022).

91. Environmental Agency of Iceland. Pjóðgarðurinn Snæfellsjökull—Verndun og Stjórnun (Trans. Snæfellsjökull National Park— Protection and Management). Available online: https://ust.is/nattura/natturuverndarsvaedi/thjodgardurinn-snaefellsjokull/ verndun-og-stjornun/ (accessed on 27 January 2022).

92. Siltanen, J. (University of Iceland, Reykjavík, Iceland). Interview with respondent 2. Personal Communication, 2022.

93. Icelandic Ministry of Environment and Natural Resources. 601/2020 Reglugerð um Gestagjöld Innan Vatnajökulspjóðgarðs fyrir veitta pjónustu og aðgang að svæðinu (trans. Regulation on Visitor Fees within Vatnajökull National Park for Services Provided and Access to the Area). Available online: https:/ /island.is/reglugerdir/nr/0601-2020 (accessed on 19 January 2022). 
94. Icelandic Parliament. 101/2016 Lög um breytingu á lögum um Vatnajökulspjóðgarð, nr. 60/2007, með síðari breytingum: Stjórnfyrirkomulag, verndaráætlun, leyfisveitingar o.fl. (Trans. Act on Amending the Act on Vatnajökull National Park, with Subsequent Amendments: Management, Protection Plan, Licensing, etc.). Available online: https://www.althingi.is/altext/stjt/ 2016.101.html (accessed on 15 January 2022).

95. Vatnajökull National Park. Stjórnunar- og Verndaráætlun Vatnajökulspjóðgarðs (Trans. Management and Protection Plan for Vatnajökull National Park). Available online: https://www.vatnajokulsthjodgardur.is/static/files/Stjornsysla/SOGV/ stjornunar-og-verndaraaetlun-20110228-stadfest.pdf (accessed on 18 January 2022).

96. Vatnajökull National Park. Stjórnunar- og verndaráætlun Vatnajökulspjóðgarðs—2. útgáfa (Trans. Vatnajökull National Park Management and Protection Plan-2nd Edition). Available online: https:/ / www.vatnajokulsthjodgardur.is/static/files / Stjornsysla/PDF-skjol-kort/stjornunar-og_verndar_2013.pdf (accessed on 18 January 2022).

97. Siltanen, J. (University of Iceland, Reykjavík, Iceland). Interview with respondent 4. Personal Communication, 2022.

98. Prime Minister's Office of Iceland. 848/2005 Reglugerð um pjóðgarðinn á Pingvöllum, Verndun hans og meðferð (Trans. Regulation on Pingvellir National Park, Its Protection and Treatment). Available online: https://island.is/reglugerdir/nr/0848-2 005 (accessed on 15 January 2022).

99. Icelandic Ministry of Environment and Natural Resources. 300/2020 Reglugerð um Vatnajökulspjóðgarðs (trans. Regulation of Vatnajökull National Park). Available online: https: / www.stjornartidindi.is / Advert.aspx?RecordID=435debd2-3e4a-49b9-ad1f01130bfb2a19 (accessed on 15 January 2022).

100. Pingvellir National Park. Management Plan 2004-2024. Available online: https://www.thingvellir.is/en/protectionmanagement/management-plan-2004-2024/ (accessed on 18 January 2022).

101. Environmental Agency of Iceland. Pjóðgarðurinn Snæfellsjökull-Verndaráætlun 2010-2020 (Trans. Snæfellsjökull National ParkManagement Plan 2010-2020). Available online: https:/ / ust.is/library/Skrar/Einstaklingar/Fridlyst-svaedi/Snaefellsjokull/ verndaraaetlun-snaefellsnes.pdf (accessed on 18 January 2022).

102. Ostrom, E.; Cox, M. Moving beyond panaceas: A multi-tiered diagnostic approach for social-ecological analysis. Environ. Conserv. 2010, 37, 451-463. [CrossRef]

103. Starnes, T.; Beresford, A.E.; Buchanan, G.M.; Lewis, M.; Hughes, A.; Gregory, R.D. The extent and effectiveness of protected areas in the UK. Glob. Ecol. Conserv. 2021, 30, e01745. [CrossRef]

104. Mannetti, L.M.; Göttert, T.; Zeller, U.; Esler, K.J. Expanding the protected area network in Namibia: An institutional analysis. Ecosyst. Serv. 2017, 28, 207-218. [CrossRef]

105. Nyaupane, G.P.; Poudel, S.; York, A. Governance of protected areas: An institutional analysis of conservation, community livelihood, and tourism outcomes. J. Sustain. Tour. 2020, 1-20. [CrossRef]

106. Badola, R.; Hussain, S.A.; Dobriyal, P.; Manral, U.; Barthwal, S.; Rastogi, A.; Gill, A.K. Institutional arrangements for managing tourism in the Indian Himalayan protected areas. Tour. Manag. 2018, 66, 1-12. [CrossRef]

107. Ogbaharya, D.G. Change and Continuity in Natural Resources Management: A Historical Institutional Analysis of Ethiopia and Namibia; Northern Arizona University: Flagstaff, AZ, USA, 2013.

108. Petursson, J.G.; Vedeld, P. The "nine lives" of protected areas. A historical-institutional analysis from the transboundary Mt Elgon, Uganda and Kenya. Land Use Policy 2015, 42, 251-263. [CrossRef]

109. Ostrom, E. Understanding Institutional Diversity; Princeton University Press: Princeton, NJ, USA, 2009.

110. Zafra-Calvo, N.; Garmendia, E.; Pascual, U.; Palomo, I.; Gross-Camp, N.; Brockington, D.; Cortes-Vazquez, J.-A.; Coolsaet, B.; Burgess, N.D. Progress toward Equitably Managed Protected Areas in Aichi Target 11: A Global Survey. BioScience 2019, 69, 191-197. [CrossRef] [PubMed]

111. Dietz, T.; Ostrom, E.; Stern, P.C. The Struggle to Govern the Commons. Science 2003, 302, 1907-1912. [CrossRef]

112. Locke, H. Nature needs half: A necessary and hopeful new agenda for protected areas. Nat. New South Wales 2014, 58, 7-17. [CrossRef]

113. Dinerstein, E.; Joshi, A.; Vynne, C.; Lee, A.; Pharand-Deschênes, F.; França, M.; Fernando, S.; Birch, T.; Burkart, K.; Asner, G. A "Global Safety Net" to reverse biodiversity loss and stabilize Earth's climate. Sci. Adv. 2020, 6, eabb2824. [CrossRef]

114. Soliku, O.; Schraml, U. Making sense of protected area conflicts and management approaches: A review of causes, contexts and conflict management strategies. Biol. Conserv. 2018, 222, 136-145. [CrossRef]

115. Ward, C.; Holmes, G.; Stringer, L. Perceived barriers to and drivers of community participation in protected-area governance. Conserv. Biol. 2018, 32, 437-446. [CrossRef]

116. Ayivor, J.S.; Nyametso, J.K.; Ayivor, S. Protected Area Governance and Its Influence on Local Perceptions, Attitudes and Collaboration. Land 2020, 9, 310. [CrossRef]

117. Visconti, P.; Butchart, S.H.; Brooks, T.M.; Langhammer, P.F.; Marnewick, D.; Vergara, S.; Yanosky, A.; Watson, J.E. Protected area targets post-2020. Science 2019, 364, 239-241. [CrossRef]

118. Schultz, L.; Folke, C.; Österblom, H.; Olsson, P. Adaptive governance, ecosystem management, and natural capital. Proc. Natl. Acad. Sci. USA 2015, 112, 7369-7374. [CrossRef]

119. Islam, M.W.; Ruhanen, L.; Ritchie, B.W. Adaptive co-management: A novel approach to tourism destination governance? J. Hosp. Tour. Manag. 2018, 37, 97-106. [CrossRef]

120. Fabricius, C.; Currie, B. Adaptive co-management. In Adaptive Management of Social-Ecological Systems; Springer: Berlin/Heidelberg, Germany, 2015; pp. 147-179. 
121. Cumming, G.S.; Allen, C.R.; Ban, N.C.; Biggs, D.; Biggs, H.C.; Cumming, D.H.; De Vos, A.; Epstein, G.; Etienne, M.; Maciejewski, K. Understanding protected area resilience: A multi-scale, social-ecological approach. Ecol. Appl. 2015, 25, 299-319. [CrossRef] [PubMed]

122. Strickland-Munro, J.K.; Allison, H.E.; Moore, S.A. Using resilience concepts to investigate the impacts of protected area tourism on communities. Ann. Tour. Res. 2010, 37, 499-519. [CrossRef] 